\title{
Arginase Inhibitory and Antioxidant Activities of Caesalpinia coriaria (Jacq.) Willd. Bark Extract
}

\author{
Arini Wulansari, Berna Elya*, Arikadia Noviani
}

\section{Arini Wulansari, Berna Elya*, Arikadia Noviani}

\section{Department of Pharmacognosy- Phytochemistry, Faculty of Pharmacy, Universitas Indonesia, Depok 16424 West Java, INDONESIA. \\ Correspondence \\ Berna Elya \\ Department of Pharmacognosy- Phytochemistry, Faculty of Pharmacy, Universitas Indonesia, Depok 16424 West Java, INDONESIA. \\ Phone No: : +6281314161497 \\ E-mail: berna.elya@gmail.com \\ History \\ - Submission Date: 29-11-2017 \\ - Review completed: 14-02-2018; \\ - Accepted Date: 03-05-2018}

DOI : 10.5530/pj.2018.6.201

Article Available online

http://www.phcogj.com/v10/i6

\section{Copyright}

(C) 2018 Phcog.Net. This is an openaccess article distributed under the terms of the Creative Commons Attribution 4.0 International license.

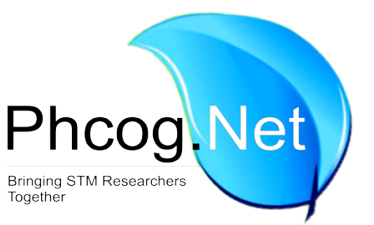

\begin{abstract}
Objective: The aim of this study was to investigate the arginase inhibitory and the antioxidant activities of the bark extract of Caesalpinia coriaria (Jacq.) Willd. (Dewi tree). Methods: The bark of Dewi tree was extracted successively under reflux condition with $n$-hexane, ethyl acetate, and methanol. Each extract was tested for its activity in inhibiting arginase activity by measuring the quantity of urea produced in the reaction mixture using a microplate reader. The active extracts were determined for their total flavonoid content followed by antioxidant activity by 2, 2-diphenyl-1-picrylhydrazyl (DPPH) method using ultraviolet-visible spectrophotometry with ascorbic acid as standard. Phytochemical screening was conducted to determine the presence of alkaloids, saponins, flavonoids, tannins, and steroids. Results: Arginase inhibitory activity test showed that the ethyl acetate and methanol extracts have average inhibition values of 14.43 and $33.59 \%$, respectively, at concentration of $100 \mu \mathrm{g} / \mathrm{mL}$. The total flavonoid content of the methanol and ethyl acetate extract were 7.75 and $6.30 \mathrm{mgQE} / \mathrm{g}$ sample, respectively. The methanol and ethyl acetate extracts showed antioxidant activity with an $\mathrm{IC}_{50}$ values of 4.720 and $3.647 \mu \mathrm{g} / \mathrm{mL}$, respectively. The ethyl acetate extract contained flavonoid, tannin, saponin, and steroid, while the methanol extract contained flavonoid, tannin, and saponin. Conclusion: In conclusion, C. coriaria bark extracts possessed low arginase inhibitory activity. The methanol and ethyl acetate extracts have good antioxidant activity.

Key words: Antioxidant activity, Arginase inhibitory activity, C. coriaria, Phytochemical Screening, Total flavonoid content.
\end{abstract}

\section{INTRODUCTION}

The genus Caesalpinia of the Caesalpiniaceae or Fabaceae family has varieties that reach over 500 species and spread throughout the world. Some species of this genus are endemic plants in some areas. Caesalpinia sappan and $C$. bonduc have been used in the treatment of inflammation and vascular diseases. C. sappan has been known to have inhibitory activity of the arginase enzyme. ${ }^{1}$ Various chemical and pharmacological studies conducted on several Caesalpinia species showed the nature and content that can be developed in the use of herbal medicines. Other species of the Caesalpinian genus that have not been observed, are thought to also have benefits in the study of bioactive molecules, which have therapeutic activity allowing for the discovery and development of safer and affordable drugs. ${ }^{2}$ Another species of genus Caesalpinia, called Caesalpinia coriaria originating from Central America has been cultivated in various countries including Indonesia and is known as the Dewi (Goddess) tree. The part of C. coriaria tree has been used in the empirical treatment among others; Bark and fruit $C$. coriaria is used in wound healing, and decoction of the fruit used in the treatment of hemorrhoids. ${ }^{3}$ However, the studies on phytochemical content and pharmacological effects of C. coriaria are still very limited although these plants have been used traditionally.

In the process of wound healing, nitric oxide (NO) has been known to have an important role. ${ }^{4} \mathrm{NO}$ is synthesized from L-arginine with NOS (nitric oxide synthase) as catalyst so that the availability of $\mathrm{L}$-arginine is an important factor in the production of NO at the wound site. Clinical studies showed that wound healing was better in patients given L-arginine supplements. ${ }^{5}$

Under certain conditions such as the presence of pro-inflammatory cytokines, hyperglycemia or reactive oxygen species, there would be an increase in the arginase activity. ${ }^{6,7}$ In addition, there are studies suggesting that arginine levels become very low after injury and arginase expression increases in wound fluid and increases with increasing periods of injury. ${ }^{8}$ The arginase enzyme which plays a role in the conversion of L-arginine into L-ornithineand urea may affect $\mathrm{NO}$ production by limiting $\mathrm{L}$-arginine substrate to NOS. This may lead to a decrease in the production of NO.,10 The increased expression of arginase may be associated with several pathophysiological conditions such as inflammation, leading to reduced L-arginine in local tissues. Therefore, the 
balance of NOS and arginase activity lead to be an important consideration for achieving an efficient wound healing. ${ }^{5,11}$ From the research data already mentioned, the inhibition of enzyme arginase could be a therapeutic strategy for various diseases associated with decreased NO. ${ }^{12}$

Some of flavonoid compounds have been already known to have arginase inhibitory activity such as epicatechin and flavanone subgroup compounds from Scutellaria indica. Considering the presence of several flavonoid compounds that may inhibit arginase, ${ }^{11,12,21}$ the total flavonoid content of the extracts which showed the inhibitory activity was determined and followed by antioxidant activity test of the extract having the highest total flavonoid content.

\section{METHODS}

\section{Plant Material}

The Caesalpinia coriaria (Jacq.) Willd. bark was obtained in a fresh condition from The Center of Plant Conservation Kebun Raya Bogor, West Java, and identified in Indonesia Science Institution (No. B-359/ IPH-3/KS/II/2017). The bark was dried in the drying cabinet and was ground with a grinder.

\section{Extraction}

About $200 \mathrm{mg}$ bark powder was weighed and extracted with multistage solvent, $n$-hexane, ethyl acetate, and methanol under reflux condition until the filtrate had more diluted color. The temperature of reflux apparatus was maintained to not exceed $80^{\circ} \mathrm{C}$. The concentrated extracts were collected and calculated for its rendement percentage.

\section{In situ arginase inhibitory activity assay}

The method used in this study was based on a previous method. ${ }^{13}$ with modification following manufacturer's protocols (Sigma Aldrich, Singapore) (EC 3.5.3.1 SSARGI01). ${ }^{14}$ Urea assay kit was obtained from Abnova Corporation, Taiwan (KA 1652). ${ }^{15}$ In this study, nor-NOHA acetate ( $N$-hydroxy-nor-arginine), obtained from Cayman Chemical USA, was used as a positive control of arginase inhibitor. The substrate and enzyme concentration used in the test were modified through optimization.

A $15 \mu \mathrm{L}$ of arginase $1 \mathrm{U} / \mathrm{mL}, 20 \mu \mathrm{L}$ of L-arginine $570 \mathrm{mM}$, and $10 \mu \mathrm{L}$ of sample solution were incubated at $37^{\circ} \mathrm{C}$ for $30 \mathrm{~min}$. After preincubating, $100 \mu \mathrm{L}$ of kit urea assay was added and incubated at room temperature for $60 \mathrm{~min}$. Arginase activity was determined by microplate reader (Epoch, USA) by measuring the quantity of urea produced in the reaction. nor-NOHA used as a positive control of arginase inhibitor.

\section{Phytochemical screening}

Phytochemical screening was performed on concentrated bark extract of $C$. coriaria to determine the content of the compounds contained in the extract. ${ }^{16}$ The alkaloid identification was performed using dragendorff, mayer, and bourchardat reagent with Catharanthus roseus leaves as positive control, flavonoid identification was performed using $\mathrm{Mg}$, hydrochloric acid $2 \mathrm{~N}$, and amyl alcohol reagents with quercetin as positive control. Steroid identification was performed with Liebermann-burchard reagent, tannin identification was performed using ferric chloride reagent and $10 \%$ gelatin solution with psidii folium as positive control. Saponin identification was performed using honeycomb froth test with Momordica charantia extract as positive control, quinone was identified with $10 \%$ natrium hydroxide reagent with turmeric as positive control, and triterpenoid identification was done using Liebermann-burchard test with Curcuma zanthorriza as a positive control.

\section{Total flavonoid assay}

The total assay of total flavonoid extract was performed based on the procedure stated in Pharmacopoeia Herbal Indonesia Supplement III 1st edition, method $2 .{ }^{17}$ It was divided into two part; making of calibration curve which used quercetin as reference, and the determination of total flavonoid content of samples. In this study, the presence of quercetin was confirmed by qualitative thin-layer chromatography (TLC) using $\mathrm{AlCl}_{3}$ $10 \%$ as reagent. The absorbance of the prepared sample was measured at wavelength of $437.5 \mathrm{~nm}$.

\section{Determination of free radical DPPH scavenging}

Antioxidant activity was carried out based on the modification of the previous study conducted by Molyneux, 2004. ${ }^{18} \mathrm{DPPH}$ solution was prepared with concentration of $100 \mu \mathrm{g} / \mathrm{mL}$ in methanol. The maximum wavelength was determined. DPPH: methanol (1:3) its absorbance was measured using UV-Vis spectrophotometer after $30 \mathrm{~min}$ incubation in the temperature of $37^{\circ} \mathrm{C}$. The bark extract which showed arginase inhibitor activity was made at concentration of $100,30,25,20,15,10,5$ and $1 \mu \mathrm{g} / \mathrm{mL}$ in methanol with the final concentration within the reaction of $25,7.5,6.25,5,3.75,2.5,1.25$, and $0.25 \mu \mathrm{g} / \mathrm{mL}$. Each test solution and reference mixed with $\mathrm{DPPH}$, with a ratio of DPPH: sample (1:1). The mixed solution was incubated in $37^{\circ} \mathrm{C}$ for $30 \mathrm{~min}$ and the absorbance of the mixture was measured with UV-Vis spectrophotometry at DPPH maximum wavelength that has been obtained. From the absorbance obtained, inhibition percentage and regression curves were made, and the linear equation was applied to calculate the $\mathrm{IC}_{50}$.

\section{RESULTS AND DISCUSSION}

\section{Extraction}

The harvested bark of Caesalpinia coriaria (Jacq.) Willd. was sorted in advance to separate the bark of the plant from other undesirable materials and then dried by aerated at a temperature to remove water content in the plant part to prevent the growth of microorganisms in the material during storage..$^{19}$ Dry stem bark was ground to enlarge the surface area to maximize the extraction.

Caesalpinia coriaria (Jacq.) Willd bark extraction was performed by a multistage extraction method using $n$-hexane, ethyl acetate, and methanol solvent. Reflux method is an extraction method that can provide a shorter extraction process with the use of a small amount of solvent. ${ }^{20}$ The extraction was performed with three repetitions for each solvent, with volume $\pm 600 \mathrm{~mL}$ for two hours for each extraction. The temperature of the water bath at the time of extraction was maintained not exceeding $80^{\circ} \mathrm{C}$ to minimize the possibility of degradation of flavonoid and phenolic compounds, ${ }^{20}$ as they were observed to possess an arginase inhibitory activity. ${ }^{21,12}$ The value of each extract rendement can be seen in Table 1.

\section{Arginase inhibitory activity test in vitro}

\section{Optimization of substrate L-arginine concentration}

Optimization of substrate concentration was done with concentration of enzyme $1 \mathrm{U} / \mathrm{mL}$ with substrate concentration series $713,650,570,300$, and $130 \mathrm{mM}$. The results are shown in Figure 1.

The optimization of enzyme and substrate concentrations carried out in this study showed a different result from the protocol suggestion of enzymatic test from manufacturers in the determination of substrate and enzyme concentration. This different result might be due to the enzyme activity that was less optimum because of the remote shipment distance from the manufacturer and might be due also to enzyme storage period factor. From these results, it showed that starting from $570 \mathrm{mM}$ substrate concentration, the absorbance no longer experienced a significant increase and tend to be stable despite a slight decrease at $650 \mathrm{mM}$ 
Elya, et al.: Arginase Inhibitory and Antioxidant Activities of C. coriaria

Table 1: Percentage of extract obtained via reflux extraction.

\begin{tabular}{cccccc}
\hline No & Solvent & Weight of powder $(\mathbf{g})$ & Total solvent volume (L) & Concentrated extract (g) & Rendement (\%) \\
\hline 1 & n-hexane & 200,38 & $3 \times 0,6$ & 0,3165 & 0,31 \\
2 & Ethyl acetate & 200,38 & $3 \times 0,6$ & 3,9315 & 1,96 \\
3 & methanol & 200,38 & $3 \times 0,6$ & 14,8782 & 7,42 \\
\hline
\end{tabular}

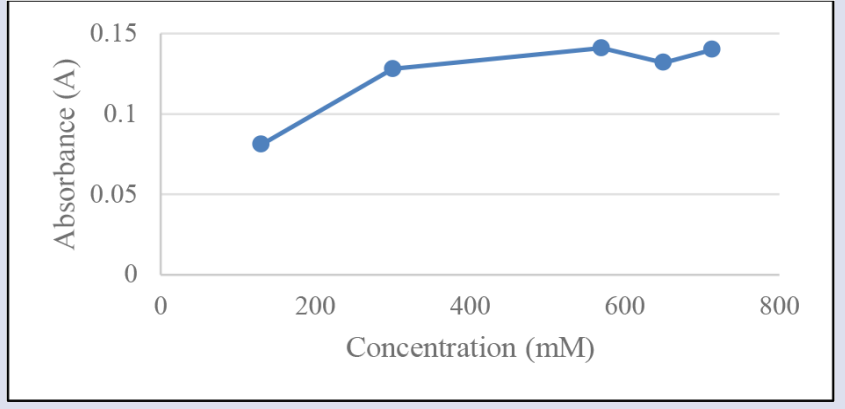

Figure 1: Optimization L-arginine substrate curve.

Table 2: Arginase inhibitory activity screening test of bark extracts.

\begin{tabular}{ccccc}
\hline $\begin{array}{c}\text { Extract sample } \\
\begin{array}{c}\text { concentration test of } 100 \\
\mu \mathrm{g} / \mathrm{mL} \text { ) }\end{array}\end{array}$ & $\begin{array}{c}\% \\
\text { inhibition }\end{array}$ & $\begin{array}{c}\% \\
\text { inhibition } \\
\text { average }\end{array}$ & SD & KV (\%) \\
\hline n-hexane & $-97,44$ & & & \\
& $-119,66$ & $-117,41$ & 18,949 & 16,14 \\
& $-135,13$ & & & \\
& 12,92 & & & \\
Ethyl acetate & 16,30 & 14,43 & 1,722 & 11,94 \\
& 14,06 & & & \\
Methanol & 28,80 & 33,59 & 4,620 & 13,75 \\
\hline
\end{tabular}

concentration. By considering at the stabilized absorbance at a concentration of $713 \mathrm{mM}$, it could be concluded that the optimum concentration of the substrate for subsequent use in the enzyme inhibition test was at a concentration of $570 \mathrm{mM}$ with a concentration of $1 \mathrm{U} / \mathrm{ml}$ enzyme.

\section{Arginase inhibitory activity test of nor-NOHA acetate}

Arginase activity inhibition test with positive control nor-NOHA acetate was done by preparing nor-NOHA solution with concentration 2.25; 4.5; $13.5 ; 18 ; 22.5 \mu \mathrm{g} / \mathrm{mL}$ (final concentration of nor-NOHA acetate in the reaction i.e. $0.5,1,3,4 ; 5 \mu \mathrm{g} / \mathrm{mL}$ ). The selection of this concentration series was based on the product information in which nor-NOHA acetate could inhibit arginase enzyme from rat macrophages in the concentration range of $2.693-3.556 \mu \mathrm{g} / \mathrm{mL}$. The result of arginase inhibitory test by nor-NOHA acetate is shown in Figure 2 Based on the obtained linear equation, the value of $\mathrm{IC}_{50}$ nor-NOHA acetate in the experiment was $3.752 \mu \mathrm{g} / \mathrm{mL}$

\section{Arginase inhibitory activity test of extracts}

Arginase activity inhibition test in vitro of bark extract of Caesalpinia coriaria (Jacq.) Willd. was began with a screening of arginase inhibitory activity of the sample extract in which results presented in Table 2.

From the test results, the extract which had the inhibitory value of arginase enzyme activity was ethyl acetate extract and methanol extract with

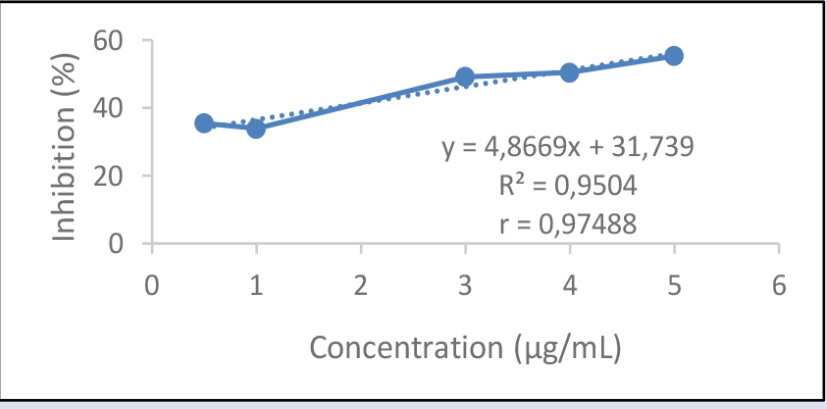

Figure 2: Graph of arginase activity inhibition of nor-NOHA acetate

an average inhibition percentage of 14.43 and $33.59 \%$ at the concentration of extract $100 \mu \mathrm{g} / \mathrm{mL}$. The extract was considered to have a good enzyme inhibitory activity if it could inhibit enzyme activity by $\geq 50 \%$ at concentrations lower or equal to $100 \mu \mathrm{g} / \mathrm{mL} .^{22}$ Meanwhile, the inhibitory value of both extracts did not reach $50 \%$ at the concentration of $100 \mu \mathrm{g} / \mathrm{mL}$ extract. Thus, the extract was considered less potent in inhibiting the activity of the enzyme arginase. Therefore, considering the low potent of the extracts and the test effectiveness, the $\mathrm{IC}_{50}$ determination of the extract was not applied in this study.

\section{Phytochemical screening}

Phytochemical screening was performed on extracts which had inhibitory values of arginase enzyme activity; ethyl acetate extract and methanol extract. The result of phytochemical screening of ethyl acetate extract and methanol Caesalpinia coriaria (Jacq.) Willd. was summarized in Table 3.

\section{Total flavonoid assay}

Determination of total flavonoid content of the sample was performed using colorimetric method of UV spectrophotometry using aluminum chloride and sodium acetate as reagents. The calculation results were then expressed as milligram quercetin equivalent per gram sample. ${ }^{23}$

Determination of total flavonoid content using aluminum chloride reagent was principled in the formation of complexes between aluminum ions $\left(\mathrm{Al}^{3+}\right)$ and carbonyl groups and hydroxyl from flavonoids that formed a yellow color. Meanwhile, the addition of sodium acetate could detect the presence of free 7-hydroxyl groups from flavones and flavonols. ${ }^{23,24}$ In this study, the determination of total flavonoid content was performed first with the standard calibration curves of quercetin in which the linear regression equation obtained was used in determining the total flavonoid content of the sample against quercetin.

The presence of quercetin of Caesalpinia coriaria bark extract sample was confirmed by qualitative thin-layer chromatography using aluminum chloride $10 \%$ as spray reagent. Ethyl acetate and methanol extracts' spots showed yellow fluorescence on observations under $366 \mathrm{~nm}$ of ultraviolet light with Rf 0.550 and 0.583 , respectively. The Rf value of ethyl acetate 
Table 3: Phytochemical screening test result.

\begin{tabular}{ccc}
\hline Group of Compound & Ethyl acetate extract & Methanol extract \\
\hline Alkaloid & - & - \\
Flavonoid & + & + \\
Tannin & + & + \\
Saponin & + & + \\
Quinone & - & - \\
Triterpenoid & - & - \\
Steroid & + & - \\
\hline
\end{tabular}

and methanol extractwas similar withthe Rf value of quercetin, where the standard $\mathrm{Rf}$ value of quercetin spot was 0.517 (as presented in Figure. 3) Preparation of standard calibration curve of quercetin was done by using concentration of $30,40,50,60,70$, and $80 \mu \mathrm{g} / \mathrm{mL}$ (final concentration in final reaction volume i.e. $3,4,5,6,7$, and $8 \mu \mathrm{g} / \mathrm{mL}$. From the measurements using UV spectrophotometry within the wavelength range of 600-400 $\mathrm{nm}$, the maximum wavelength was detected at $437.5 \mathrm{~nm}$. The maximum wavelength was a slight different compared to the research done by Pontis et al. ${ }^{23}$ Therefore, this maximum wavelength was used in the determination of flavonoid of the samples. The standard calibration curve obtained from quercetin test was shown in Figure 4. with linear regression equation $y=-0.0008+0.0695 x$ (with $r$ value $=0.99889)$.

The total flavonoid determination of the active extracts showed the average total flavonoid content of ethyl acetate and methanol extracts were 6.30 and $7.75 \mathrm{mgQE} / \mathrm{g}$ samples, respectively. Despite the low arginase inhibitory activity of the methanol extract, the total flavonoid content in methanol extract which had greater value than ethyl acetate extract could be considered in line with the percentage of inhibition of arginase enzyme activity performed, where the percent value of inhibition of methanol extract was greater than ethyl acetate extract. It was also supported by several studies which stated that some compounds which could inhibit the activity of enzyme arginase generally include flavonoid groups, such as epicatechins, flavanone subgroup compounds from plants Scutellaria indica, and others. ${ }^{12,21}$ The low potent of arginase inhibitory activity of the extracts might be due to the chemical structure differences between flavonoid and phenolic compounds contained in the extracts compared to the compound which had already observed to have a good arginase inhibitory activity. The lack of catechol group bonded in the flavonoid found in the extract drastically decreased arginase inhibition. ${ }^{12}$ Otherwise, the medicinal chemistry approach should be observed

\section{Antioxidant activity with DPPH method}

The result of DPPH wavelength optimization test showed that DPPH showed maximum absorbance at $516 \mathrm{~nm}$. Therefore, the maximum wavelength $516 \mathrm{~nm}$ was used in the standard ascorbic acid DPPH test and the extract sample.

In DPPH test with ascorbic acid as standard, ascorbic acid showed $\mathrm{IC}_{50}$ value of $3.0176 \mu \mathrm{g} / \mathrm{mL}$ with the inhibition graph presented in Figure 4 . Meanwhile, methanol and ethyl acetate bark extracts showed $\mathrm{IC}_{50}$ value of 4.720 and $3.647 \mu \mathrm{g} / \mathrm{mL}$, respectively. The $\mathrm{IC}_{50}$ value of both extracts were considered very potent antioxidant in inhibiting DPPH free radicals. The DPPH inhibition graph by methanol and ethyl acetate bark extracts were presented in Figure 5 and 6.

\section{CONCLUSION}

Caesalpinia coriaria bark extract (Jacq.) Willd. had a low arginase inhibitory activity where at concentrations of $100 \mu \mathrm{g} / \mathrm{mL}$, ethyl acetate extract and methanol bark of Caesalpinia coriaria (Jacq.) Willd. showed an average

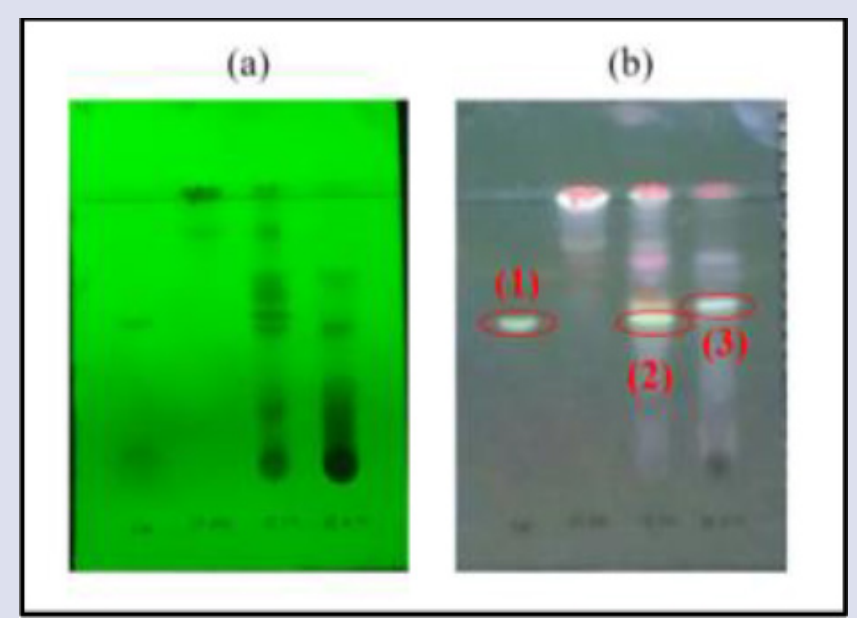

Figure 3: Qualitative thin-layer chromatography of extracts in determination of quercetin presence.

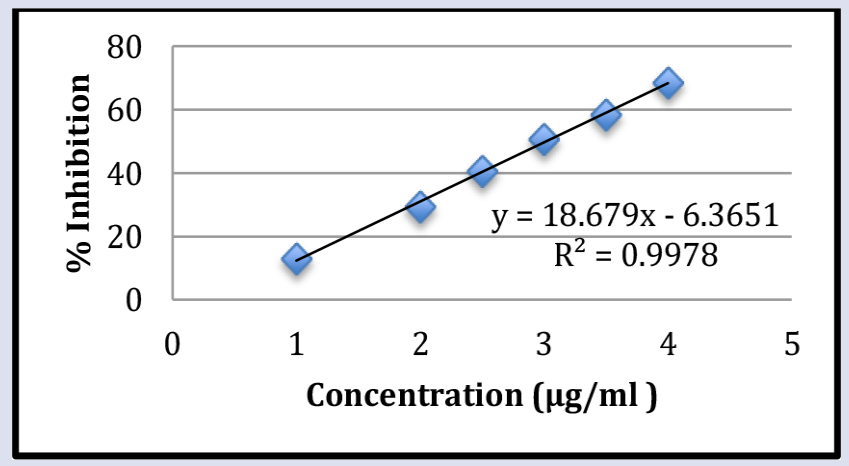

Figure 4: $\mathrm{IC}_{50}$ curve of ascorbic acid as antioxidant activity test reference.

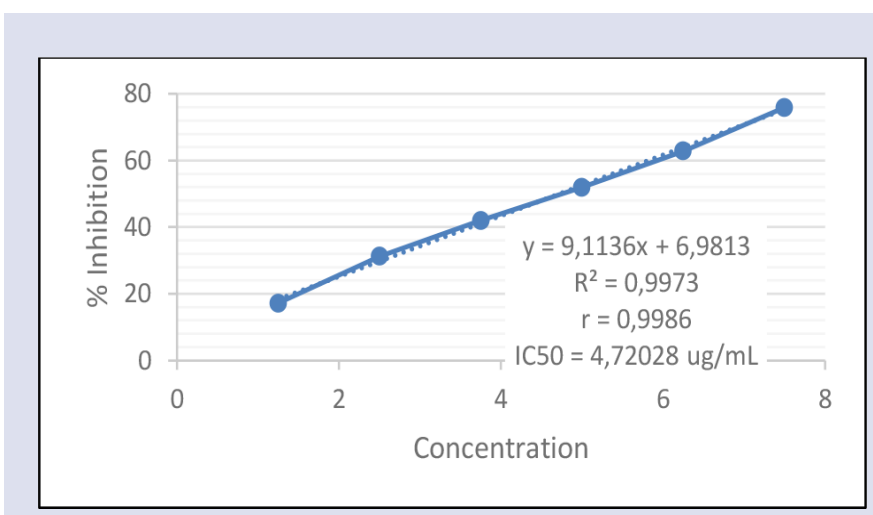

Figure 5: The DPPH inhibition graph by methanol bark extract.

inhibition percentage value of arginase enzyme activity of 14.43 and $33.59 \%$, respectively. The chemical compound groupsfound in ethyl acetate extract of Caesalpinia coriaria (Jacq.) Willd. bark were flavonoids, tannins, saponins, and steroids. Meanwhile, the chemical compoundgroups contained in methanol bark extract of Caesalpinia coriaria (Jacq.) Willd. were flavonoids, tannins, and saponins. The average of total flavonoid 


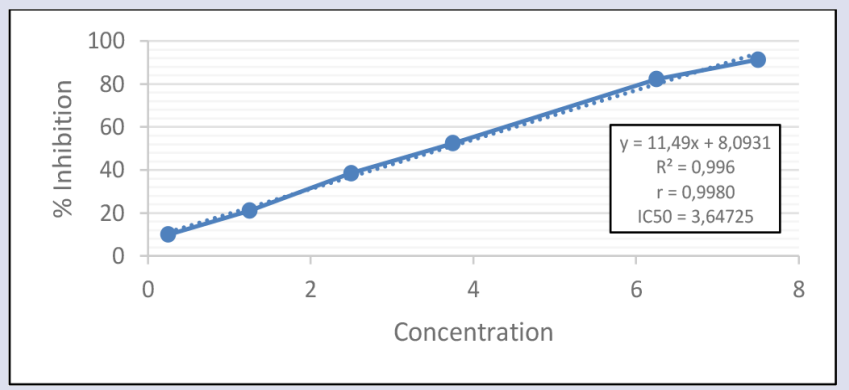

Figure 6: The DPPH inhibition graph by ethyl acetate bark extract.

content of ethyl acetate and methanol bark extracts of Caesalpinia coriaria (Jacq.) Willd. were 6.30 and $7.75 \mathrm{mgQE} / \mathrm{g}$ sample, respectively. Methanol and ethyl acetate extracts were considered as potent antioxidants with an $\mathrm{IC}_{50}$ value of 4.720 and $3.647 \mu \mathrm{g} / \mathrm{mL}$, respectively, in antioxidant activity test with DPPH, while ascorbic acid had $\mathrm{IC}_{50}$ value of $3.0176 \mu \mathrm{g} / \mathrm{mL}$.

\section{ACKNOWLEDGEMENT}

The authors are highly thankful to Universitas Indonesia who had given a financial support for this research, particularly for PITTA Research Grants 2017

\section{CONFLICT OF INTEREST}

The authors declare no conflict of interest.

\section{ABBREVIATIONS}

C. coriaria: Caesalpinia coriaria; NO: Nitric oxide; NOS: Nitric Oxide Synthase; DPPH: 2,2-diphenyl-1-picrylhydrazil; UV: Ultraviolet; norNOHA: N-hydroxy-nor-arginine; QE: Quercetine Equivalent

\section{REFERENCES}

1. Shin WS, Cuong TD, Lee JH, Min B, Jeon BH, Lim HK. et al. Aginase inhibition by ethylacetate extract of Caesalpinia sappan lignum contributes to activation of entothelial nitric oxide synthase. Korean Journal of Physiology and Pharmacology. 2011;15(3):123-8.

2. Zanin JLB, Carvalho BA, Martineli PS, Dos Santos MH, Lago GJH, Sartorelli P, Viegas CJR, Soares, M.G. The genus Caesalpinia L. (Caesalpiniaceae): phytochemical and pharmacological characteristics. Molecules. 2012;17(7):7887-902.

3. Fern, Ken. Useful Tropical Plants Database: "Caesalpinia coriaria." 2014. http:// tropical.theferns.info/viewtropical.php?id=Caesalpinia+coriaria (accessed on Oktober $17^{\text {th }}$ 2016).
4. Gould A, Naidoo C, Candy GP. Arginine metabolism and wound healing. Wound Healing Southern Africa. 2008;1(1):48-50.

5. Kämpfer $H$, Pfeilschifter J, Frank S. Expression and acivity of arginase isoenzymes during normal and diabetes-impaired skin repair. The Journal of Investigative Dermatology. 2003;121(6):1544-51.

6. Chandra S, Romero MJ, Shatanawi A, Alkilany AM, Caldwell RB, Caldwell RW Oxidative species increase arginase activity in entothelial cells through the RhoA/Rho kinase pathway. British Journal of Pharmacology. 2012;165(2):506-19.

7. Gao X, Xu X, Belmadani S, Park Y, Tang Z, Feldman AM, et al. TNF- $\alpha$ contributes to endothelial dysfunction bu upregulating arginase in ischemia/reperfusion injury. Arteriosclerosis Thrombosis and Vascular Biology. 2007;27(6):1269-75.

8. Rizk M, Witte MB, Barbul A. Nitric oxide and wound healing. World Journal of Surgery. 2004;28(3):301-6.

9. Ryoo S, Lemmon CA, Soucy KG, Gupta G, White AR, Nyhan D, et al. Oxidized low-density lipoprotein-dependent endothelial arginase II activation contributes to impaired nitric oxide signaling. Circulation Research. 2006;99(9):951-60.

10. Durante W. Role of arginase in vessel wall remodeling. Frontiers in Immunology. 2013;4:111.

11. Schnorr O, Brosette $T$, Momma TY, Kleinbongard $P$, Keen $C L$, Schroeter $H$, et al. Cocoa flavanols lower vascular arginase activity in human endothelial cells in vitro and in erythrocytes in vivo. Archives of Biochemistry and Biophysics. 2008;476(2):211-5

12. Thernier-Girard C, Pham TN, Demougeot C. The promise of plant-derived substances as inhibitors of arginase. Medicinal Chemistry. 2015;15(10):798-808.

13. Kavalukas SL, Uzgare AR, Bivalacqua TJ, Barbul A. Arginase inhibition promotes wound healing in mice. Surgery. 2012:151(2):287-95.

14. Sigma-Aldrich Co. LLC. Enzymatic Assay of Arginase. 1997; St. Louis, Missouri: Author.

15. Abnova Corporation. Urea assay kit. 2007; Taoyuan: Author.

16. Indonesia DK. Materia Medika Indonesia Jilid VI. 1995; Jakarta:Departemen Kesehatan Republik Indonesia.

17. Kementrian Kesehatan RI. Direktorat Jenderal Bina Kefarmasian dan Alat Kesehatan. Farmakope Herbal Indonesia Suplemen III Edisi I. 2013; Jakarta: Kementrian Kesehatan Rl.

18. Molyneux, P. The Use of the Stable Free Radical Diphenylpicryl-hydrazil (DPPH) for Estimating Antioxidant Activity. Songklanakarin Journal of Science and Technology. 2004;26(2):211-9

19. World Health Organization. Maintenance Manual for Laboratory Equipment 2008.

20. Khoddami A, Wilkes MA, Roberts TH. Techniques for analysis of plant phenolic compounds. Molecules. 2013;18(2):2328-75.

21. Ghasemzadeh A, Dan Jaafar HZE. Optimization of reflux conditions for total flavonoid and total phenolic extraction and antioxidant capacity in pandan (Pandanus amaryllifolius Roxb.) using response surface methodology. The Scientific World Journal. 2014;1-10.

22. Nair SS, Kavrekar $V$, Mishra A. In vitro studies on alpha amylase and alpha glucosidase inhibitory activities of selected plant extracts. European Journal of Experimental Biology. 2013;3(1):128-32

23. Pontis JA, Da Costa LAMA, Da Silva SJ, Flach A. Color, phenolic and flavnonoid content, and antioxidant activity of honey from Roraima Brazil. Food Science Technology Campinas. 2014;34(1):69-73.

24. Markham KR. Cara mengidentifikasi flavonoid. 1988; Bandung: Penerbit ITB
GRAPHICAL ABSTRACT

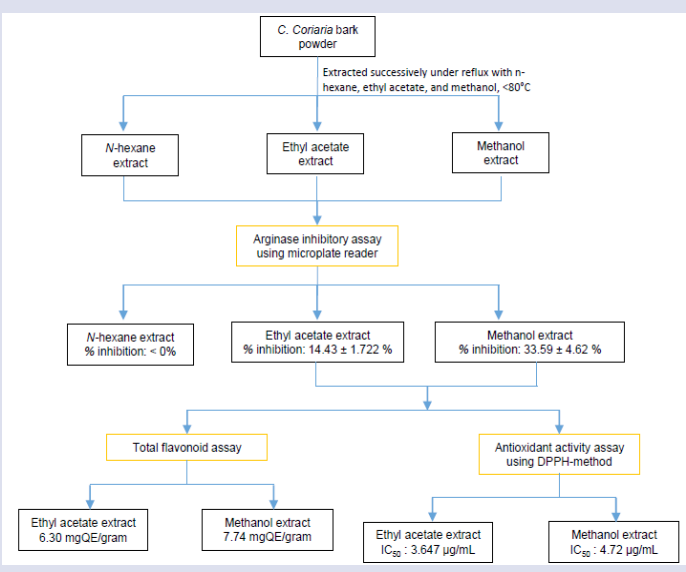

\section{SUMMARY}

- The bark of $C$. coriaria was extracted successively with n-hexane, ethyl acetate, and methanol under reflux condition. The obtained extracts were tested for arginase inhibitory activity. The extracts which showed an arginase inhibitory activity were followed by total flavonoid content and antioxidant activity tests.

- Arginase inhibitory test by using microplate reader with nor-NOHA acetate as standard, showed that ethyl acetate and methanol extracts had average inhibition values of 14.43 and $33.59 \%$, respectively.

- Total flavonoid assay conducted on the active extracts showed that the total flavonoid content of ethyl acetate and methanol extract were 6.30 and 7.75 mgQE/gram, respectively.

- Antioxidant assay by using DPPH method using ultraviolet-visible spectrophotometry with ascorbic acid as standard, showed that ethyl acetate and methanol extracts showed antioxidant activity with an $I C_{50}$ value of 3.647 and 4.7203 $\mu \mathrm{g} / \mathrm{mL}$, respectively.

- The highest arginase inhibitory and antioxidant activity of samples was obtained from methanol extract 


\section{ABOUT AUTHORS}

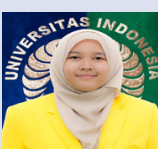

$\underline{1}+2000$
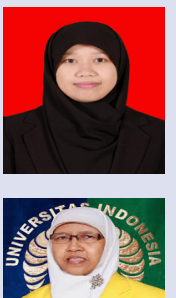

Berna Elya: is a Professor at the Faculty of Pharmacy, Universitas Indonesia. She is the Head of Laboratory of Phytochemistry and Pharmacognosy. Has expertise in the area of Pharmacognosy and Phytochemistry of Natural Products, working mainly in: Natural Product Isolation and Bioassay.

Cite this article: Wulansari A, Elya B, Noviani A. Arginase Inhibitory and Antioxidant Activities of Caesalpinia coriaria (Jacq.) Willd. Bark Extract. Pharmacog J. 2018;10(6):1174-9. 